\title{
Effects of Intervention of Street Vendors on Public Spaces of Tegalega Park, Bandung, Indonesia
}

\author{
Sudarisman, Irwan $^{1}$, Mustafa, Muhizam ${ }^{2 *}$, and Mohd Isa, Mohd Hafizal ${ }^{3}$ \\ ${ }^{1}$ Universiti Sains Malaysia, ${ }^{1}$ Telkom University, ${ }^{2,3}$ Universiti Sains Malaysia \\ *Corresponding author: irwan.sudarisman@student.usm.my
}

\begin{abstract}
The intervention of street vendors to urban public space brings various negative impacts, in addition to positive impacts on the economy. This problem is more complicated and difficult to obtain solution when the number of street vendors who occupy the public space gets bigger. This phenomenon is very visible in the Tegalega Park in Bandung which has an area of 16 hectares and is the largest park in the city of Bandung. Based on a research conducted in 2014 by Indonesian University of Education (UPI) and Bandung city Bappeda the number of street vendors in four areas of Cicadas, Tegalega, Sukajadi, and Burangrang amounted to 9,118 traders. Knowledge about the effects from the presence of street vendors in Tegalega Park is important as a consideration factor in planning the design of public spaces (park) in the future so as to anticipate the problems that may arise. The documentation and analysis of activities within the park which are grouped into non-commercial activities (leisure, play and exercise) and commercial activities (trade) are used as a tool to determine the effects. The results showed that the presence of street vendors' activity led to the formation of different patterns of zoning activity compared to the initial planning of zoning of park activity.
\end{abstract}

Keywords: Street Vendors, Activity, Intervention, Park, Zoning

\subsection{INTRODUCTION}

Street vendors are business people who have the characteristics of having small capital, are not organised, do not have special abilities or skills, their economic activities are carried out alone, generally do not have a business license, and use public space as a place to do their business. Community groups that are street vendors mostly come from lower economic groups that have low education level or skills. According to Breman (1988) and as mentioned by Islahuddin (2017), street vendors are small businesses carried out by low-income people (daily salaries) and have limited capital. In the economic field, small traders are included in the informal sector, namely temporary, unskilled jobs, groups that are not bound of by the rule of law.

Many street vendors have sprung up in the big cities of Indonesia. This phenomenon occurs because of several factors, namely: large numbers of rural population migration, high levels of economic inequality, low education levels, and economic crisis. Alisyahbana (2005) quoted in Ramadhan (2015), discussed that the choice of being a street vendor is usually motivated by compulsion because there is no other job.

Population migration from village to city occurs due to the lack of employment opportunities in the village, low level of welfare and greater wages in the city. The large level of economic inequality in urban areas causes uneven opportunities to various facilities, especially education (Ramadhan, 2015). Employment opportunities are limited and not comparable to the magnitude of the needs and this condition is exacerbated by the economic crisis in Indonesia in 1998. The crisis caused many industries and companies to be closed, resulting in the termination of employment (Pramono, 
2015). This condition forced the low economic community to look for other sources of income to fulfil their needs. They choose to work as street vendors by selling various products or services.

The city of Bandung as one of the major cities in Indonesia also experienced rapid growth of street vendors. The city of Bandung is known as a tourist destination and is advanced in industry and commerce, especially textiles and creative industries. It has education centres, and close to the metropolitan city of Jakarta has caused a high flow of migration to the city. The development of the population which is not comparable to employment growth has caused street vendors to mushroom in the city of Bandung. Based on data from a 2014 survey by the Indonesian University of Education together with Bappeda in the city of Bandung (berita24.bisnis.com), most of the street vendors are migrants, both from outside the city and even outside Java. Based on data from all Sub-Districts in the City of Bandung and collected by the Bandung City Office of Cooperatives, SMEs, Industry and Trade authorities (Batlajeri and Sukaesih, 2015), the number of street vendors in 2012 is 20,326. Based on a 2014 study by the Indonesian University of Education and the Bandung City Bappeda (berita24.bisnis.com), the number of street vendors around Tegalaga Park (the subject site) is 9,118 traders.

Street vendors serve the needs of local community, especially the people from the middle to lower economic class. This, however has a negative impact on both the city community and the city itself. The street vendors in conducting their business use the public spaces in the city. As quoted by Ramadhan (2015), street vendors are often found in the public spaces of the city. The problem arises when the public space that is used by these vendors for trading or service is not in accordance with the original function of the public space. In addition, street vendors who occupy the public space tend to limit or even eliminate the rights of other users in using the space (Hafidha and Qonita, 2014). Initially, street vendors will only occupy part of the public spaces which include the road boundaries as well as pedestrian to motorised vehicles parking space as a place to do business. However, lately, these vendors tend to occupy other public spaces such as parks, plazas, parking areas, shopping mall entrances, offices, health facilities, schools, government and terminals (Budi, Ari S., 2006).

In spite of the issuance of notices with respect to regulations, activities of data collection and the control of street vendors which have been carried out by the government, the problem has not been overcome. The failure of local council efforts is due to several aspects, namely the lack of regulation dissemination, lack of rules enforcement, the intervention by providing alternative location causing a significant decrease in business income of street vendors (Wicaksono, and Rachmawati, 2015).

Tegalega Park is a public space in the form of a park that has various functions for the community located within the city of Bandung. Tegalega Park has an area of 16 hectares is one of the largest parks in the city of Bandung. Tegalega Park functions as an area that provides the recreational and socialising space for the citizens of Bandung. Tegalega Park is located at the southern part of the city, bordered by main roads, namely Mochammad Toha Street, Otto Iskandar Dinata Street and BKR Road. These roads connect the western part of Bandung with the East as well as the North with the South. They serve as the connecting pathways to economic centres, residential areas, and the city centre. Tegalega Park area in the west is bordered by commercial area in the form of Chinatown shops while the east is bordered by residential, education and government offices. The northern part has residential areas and urban transport terminals while the south has residential and commercial developments.

Street vendors, at the beginning of their appearance around the Tegalega park area, occupy the pedestrian area next to the Otto Iskandar Dinata road and Mochammad Toha road. The area is sited next to the fence on the West and East sides of the park. The street vendors' business at the park's outer area is dominated by food and beverage, while the business to the outside area is dominated by food and beverage sellers as well as those that sell raw materials for daily needs. 
The number of street vendors around the park continued to grow, especially after the monetary crisis in 1998. The growth has caused the area that was once a pedestrian area became wider that has crowded to the road. In the early 2000s, the city of Bandung was enlivened by the emergence of retail centre for used clothing called "Cibadak Mall". Since the presence of this mall has caused uncleanliness and congestion, the government relocated the traders into the Tegalega park area. This business place is known as "Candle Market" as the night activities used candles as lighting. The street vendors were then relocated to the Gedebage Market in the East Bandung area. However, some traders remained in the park after the relocation. With the growth of traders around the park, the business Bandung city government had decided to move the traders into the park and limit the time for traders. However, this attempt was not successful as the traders still conduct their activities outside the park.

The conduct of doing business in Tegalaga Park has brought significant changes to both the park and park users. These changes have a negative impact on the park as the areas that are dedicated for parking and sporting activities are constricted and the overflow of street vendors has caused the area to be unusable for its original purpose. In the effort to improve and revitalise the park, a design competition was held in 2016. However, this effort was unsuccessful as there was a lack of study on the street vending activities. Taking these aspects into considerations, design intervention to revitalise Tegalega park is necessary. With the intervention, the city government or planners would take into consideration the proposed design for improvement of parks with the same situation. It is expected that through the careful consideration of the influence of street vendors to the park, the resulting design can minimise problems that may arise after the revitalization process is carried out.

\subsection{METHODOLOGY}

This study uses an analytic descriptive research approach that aims to describe and analyse the influence of the presence of street vendors on Tegalega park. According to Furchan (2004), descriptive research approach has the following characteristics:

1. Descriptive research tends to describe a phenomenon as it is by reviewing it regularly, prioritising objectivity and provide review carefully.

2. Absence of treatment given or controlled, and absence of tests.

The subjects for in this study are street vendors who carried out commercial activities (business) inside Tegalega Park. The object in the study is the influence of street vendors on changes in park zoning based on the activities that occur in it (differentiated into commercial and noncommercial). This is the phenomenon that needs reviewing to highlights its objectivity.

This study uses data analysis that is based on the division of the park area (the park is divided into four discussion areas), while the focus of the discussion (zoning, density point and physical condition) is through a descriptive approach. This data analysis consists of two parts: the first, is an analysis of the results of documentation and the second, is an analysis of the data from field observations related to the pattern of activity that occurs (zoning), the density points formed and the physical condition of the park. Data are analysed by means of presentation in the form of tables and thereafter, conclusions are then made. This observation was conducted on Saturdays and Sundays, between 7 am and 11 am when the numbers of street vendors and visitors are the highest. 
The framework that has been developed for this study is shown in Figure 1.

Figure 1: Framework

source: personal analysis

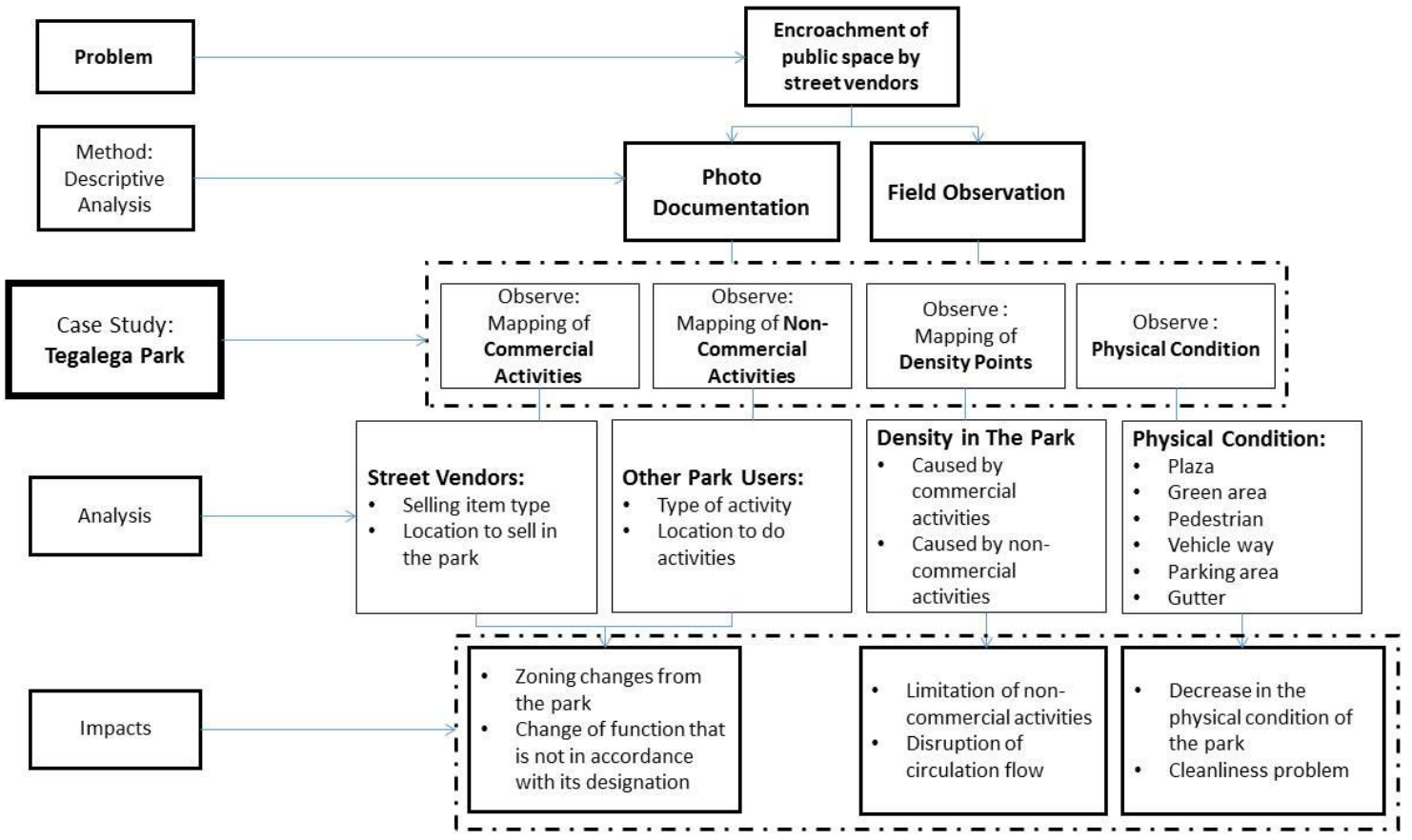

\subsection{RESULT}

Tegalega Park is where the research object is located. The park is bounded by the Otto Iskandar Dinata road, BKR road, Mochammad Toha street and the Tegalega Gang road. Tegalega Park has a swimming pool, soccer field, running track, basketball court, mosque, toilet, motorised vehicle parking area, boulevard, Bandung Lautan Api Monument, green areas, motorised lanes and pedestrian paths. During the holidays, Tegalega Park is very crowded with visitors and street vendors. Street vendors are spread in various areas and dominate the activities in the park. For the purpose of this study, Tegalega Park is divided into four study areas. The aerial view of Tegalaga Park is shown in Figure 2.

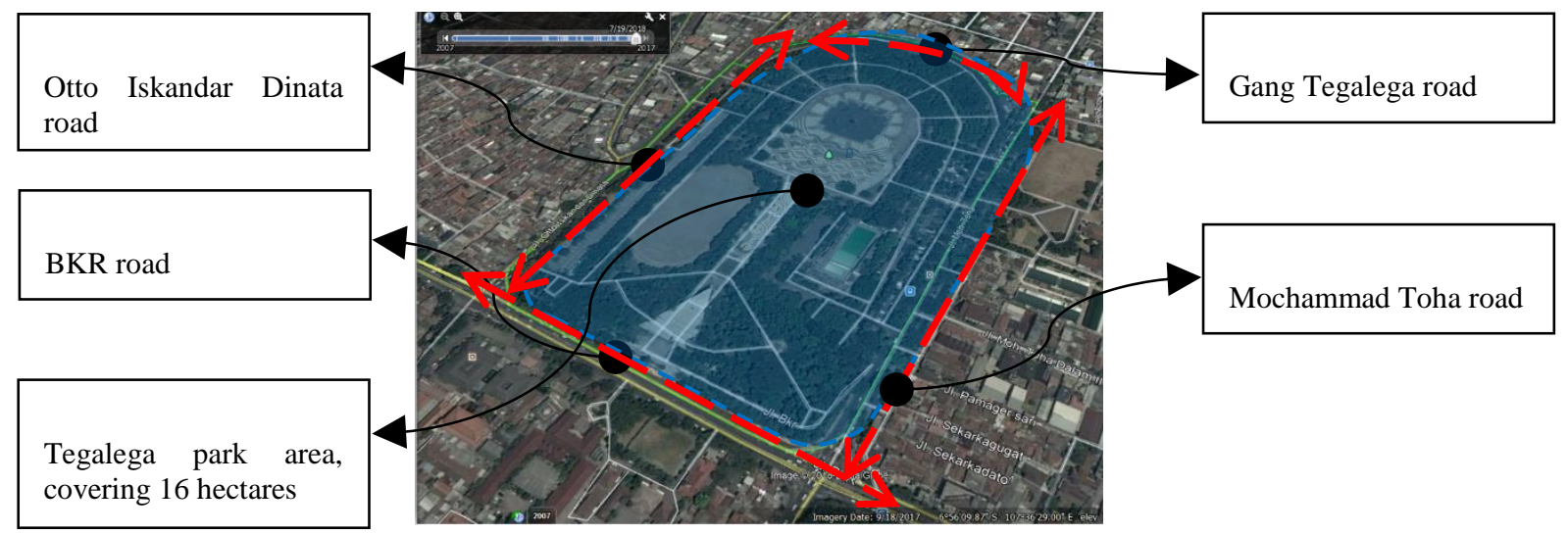

Figure 2: Tegalega park aerial view source: personal analysis (map image taken from Google Earth) 


\subsection{Study Area I (Zone I)}

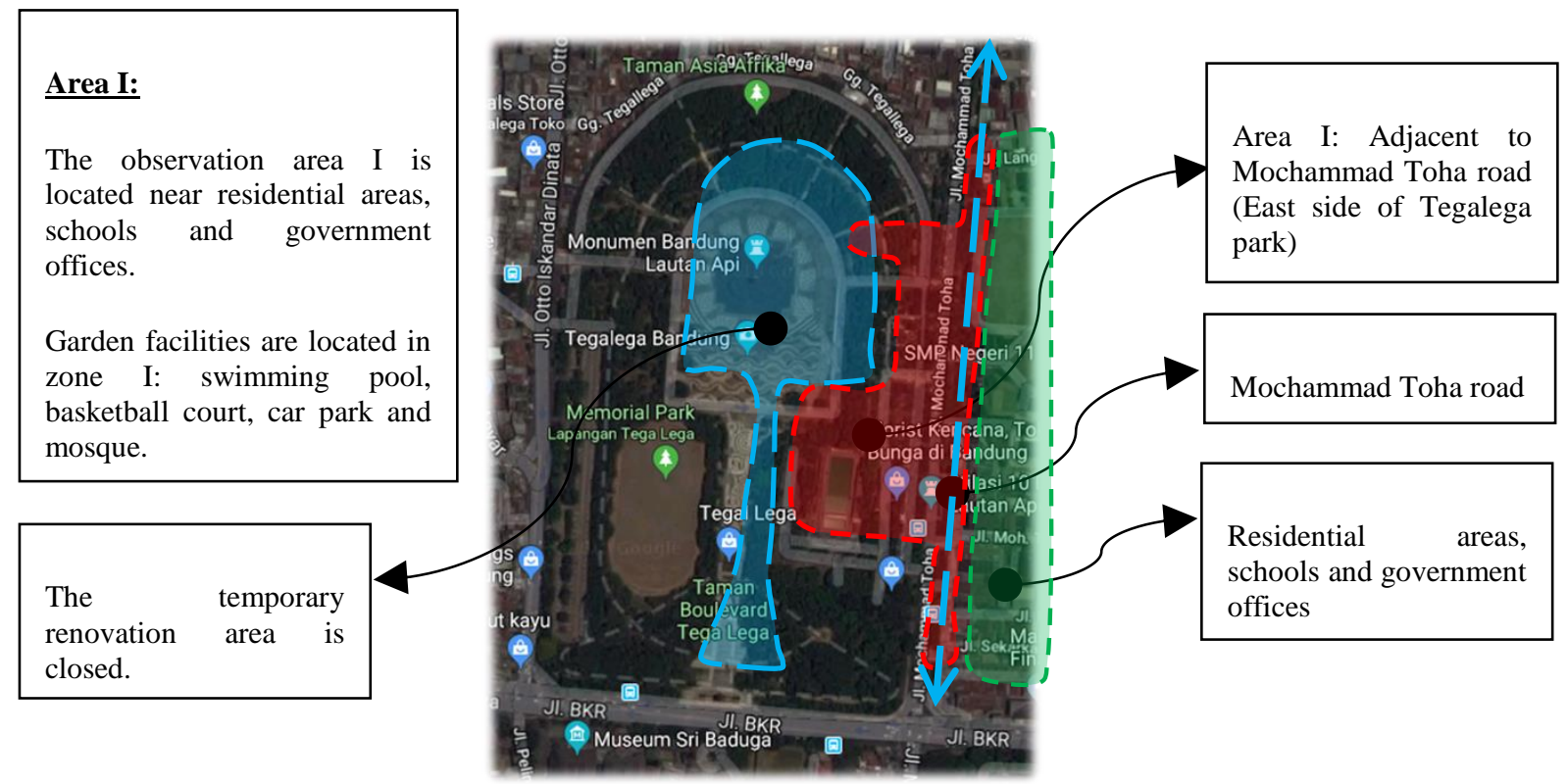

Figure 3: Zone I aerial view

source: personal analysis (map image taken from Google Map)

The research area I (located close to Mochammad Toha road) is divided into several zones, namely: pedestrian zone, motorised vehicle zone, green zone, plasa zone, parking zone, and sports zone (basketball and swimming). This area is dominated by street vendors who sell raw materials for food (meat, vegetables, fruits, herbs, etc.), household appliances, clothing, accessories, decorative flowers, food and drinks. An aerial view of Zone I is shown in Figure 3.

\subsubsection{Mapping of Commercial Activities}

Street vendors take advantage of pedestrian paths, motorised vehicle lanes, parking areas, plaza and green areas as the places to conduct business. This activity causes changes in zone designation, namely: pedestrian zones and motorised vehicles area are located on the outer side of the park (East side) that turned into a street vendor zone that sells food, household appliances, clothing, accessories and medicines. The zone formed is the shopping zone for daily needs, culinary zone and fashion zone. The motorised vehicle lane zone at the entrance to the Bandung Lautan Api Monument (East side) has been turned into a street vendor zone that is dominated by household items, fashion and food / drink needs (culinary). The plaza zone that is close to the swimming pool facility is turned into a street vendor zone that has both culinary and plaza zones. This plaza also functions as a motorbike parking zone. The parking area of motorised vehicles that are located near the swimming pool facilities is transformed into a street vendor zone and also functions as a zone for gymnastics and martial arts activities, especially for groups of old citizens. This zone forms the culinary and sports zones. The green zone which is located on the south side of the park has changed to be a garbage zone where the remnants of the street vendor's business are left. The images of the usage of the area are shown in Figure 4 and Figure 5. 

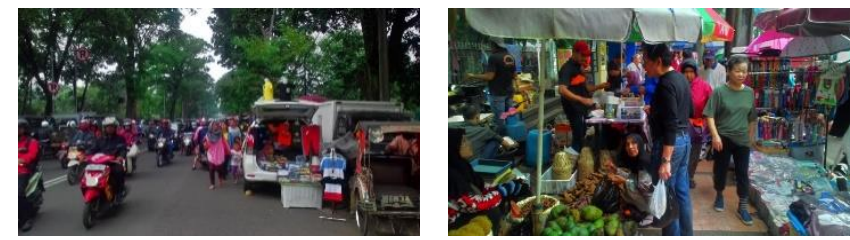

Figure 4: Images of street vendors use at parking areas, pedestrians and sewers source: personal analysis
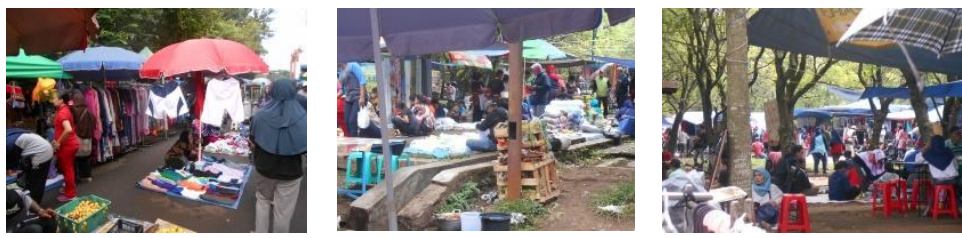

Figure 5: Images of street vendors use vehicle track areas, pedestrians and green areas source: personal analysis

\subsubsection{Mapping of Non-Commercial Activites}

The types of activities carried out by park users are playing basketball and gymnastics. The location used for these activities is at the basketball courts, parking areas and motorised vehicle lanes. Figure 6 shows the image of the use on the basketball court.

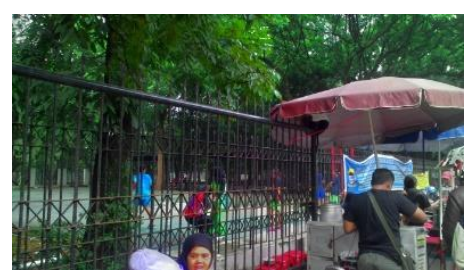

Figure 6: Image of activity at the basketball court source: personal analysis

\subsubsection{Mapping of Density Point}

It is observed that the density occurs at several points due to the presence of street vendors. The points of high density are at the two park entrance areas on the East side, along the pedestrian path adjacent to the Mochammad Toha road and along the motorised lane that leads to the monument area in the park, plaza area and motorised vehicle parking area. Figure 7 and Figure 8 show the areas of high density at the study area I. 

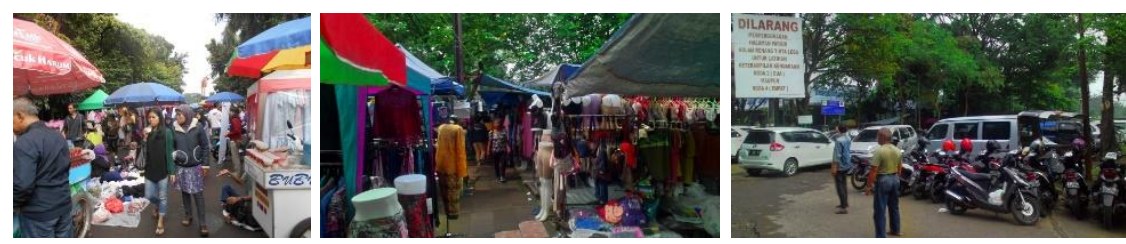

Figure 7: Image of the high density point at the pedestrian paths, vehicle lanes and parking areas, source: personal analysis
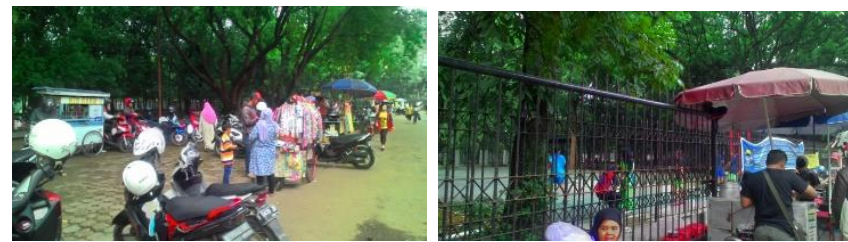

Figure 8: Image of the high density point at the plaza and near basketball court source: personal analysis

\subsubsection{Mapping of Physical Condition}

The physical condition of the park has deteriorated, namely the green areas, pedestrians, plaques and gutters. The green area is damaged as it is used as a place of business and a temporary landfill. Pedestrian paths have been damaged as they are used as motorbike parking lots.The plaza was damaged as it was used as a place to sell food using carts and motorbike parking. In addition, sewers become dirty because they are used as a place to dispose of garbage, especially organic waste. Figure 9 shows the deterioration condition of the area within the Study Area I.
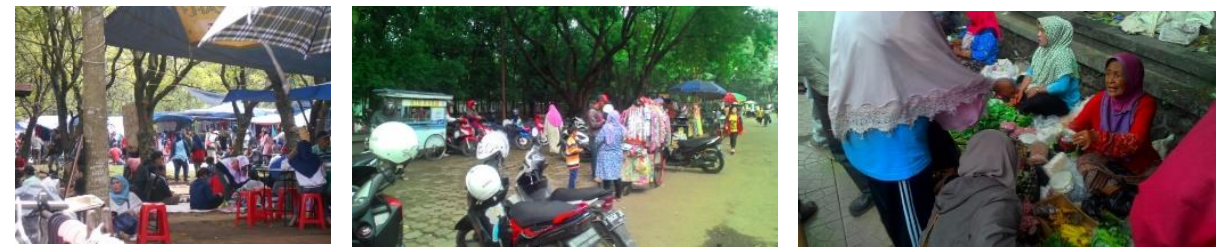

Figure 9: Image of the deterioration of the physical conditions of plaza, green areas and sewers source: personal analysis 


\subsection{Study Area II (Zone II)}

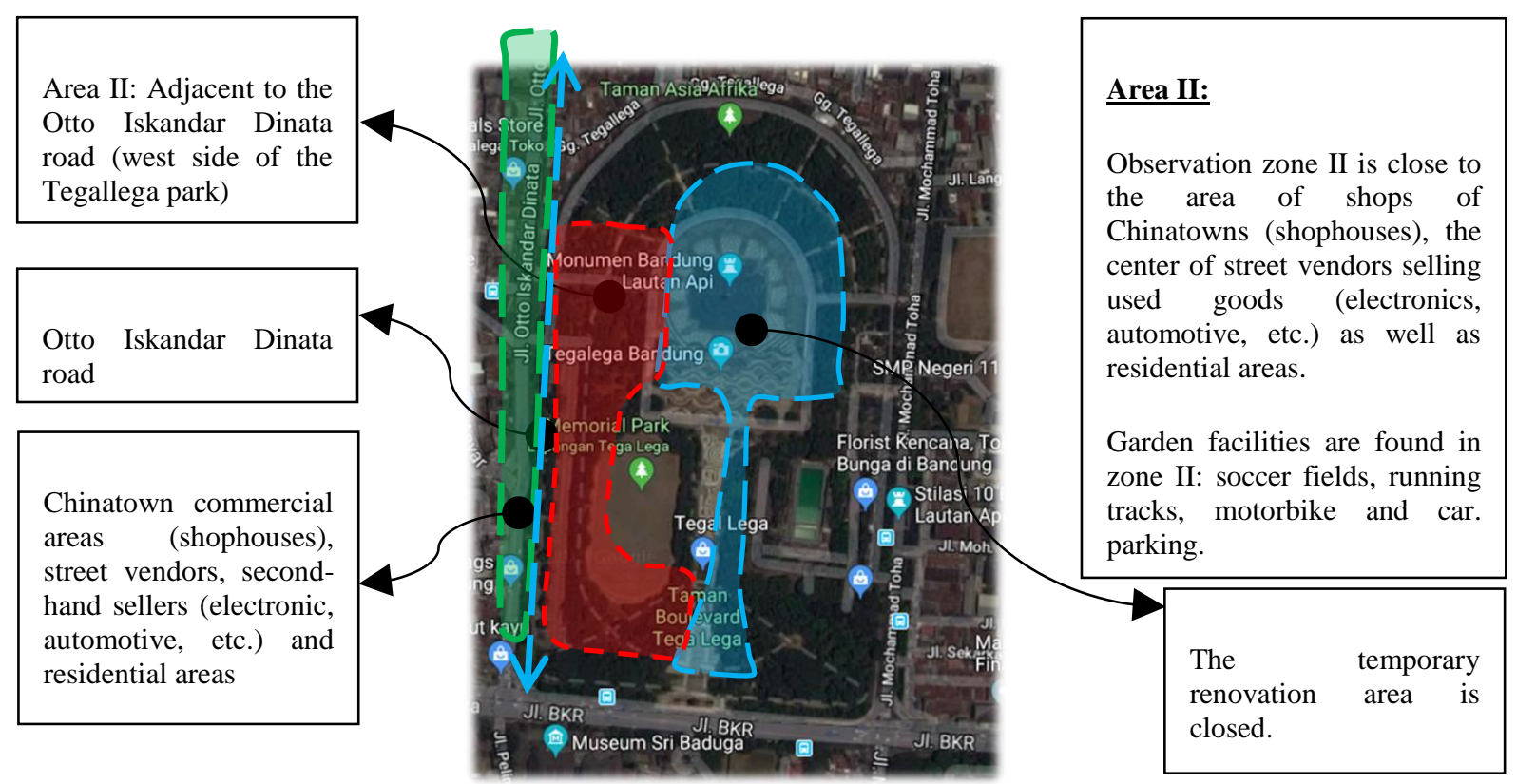

Figure 9: Zone II aerial view

source: personal analysis (map image taken from Google Map)

The study area II, located close to the Otto Iskandar Dinata road, is divided into several zones, namely: pedestrian zone, motorised vehicle zone, green zone, parking zone, and sports zone (soccer and running). This area is dominated by street vendors who sell clothing, footwear (shoes and sandals), accessories, food and drinks. In addition, there are also several street vendors who sell raw materials for food (cooking spices), household appliances, medical services and children's playground rental services. The setting of this zone has caused changes on zone designation, density and physical condition of the park.

\subsubsection{Mapping of Commercial Activities}

The motor vehicle lane zone at the entrance gate to the Bandung Lautan Api Monument (West side) has been turned into a street vendor zone dominated by fashion items. The zone formed is dominated by fashion shopping zone. The pedestrian zone which is close to the soccer field and green area has been turned into a street vendor zone that is dominated by household items and food / drink needs (culinary). The green zone that is close to the motorised parking area on the west side has been turned into a street vendor zone that are dominated by for food and drink (culinary) and services. The motorised parking zone on the west side has been turned into a street vendor zone that are dominated by culinary and fashion items, and the formed zone is a culinary zone and fashion shopping zone. Figure 10 shows the image of the street vendors usage of the area in Zone II. 


\section{e-issn: $2229-8568$}
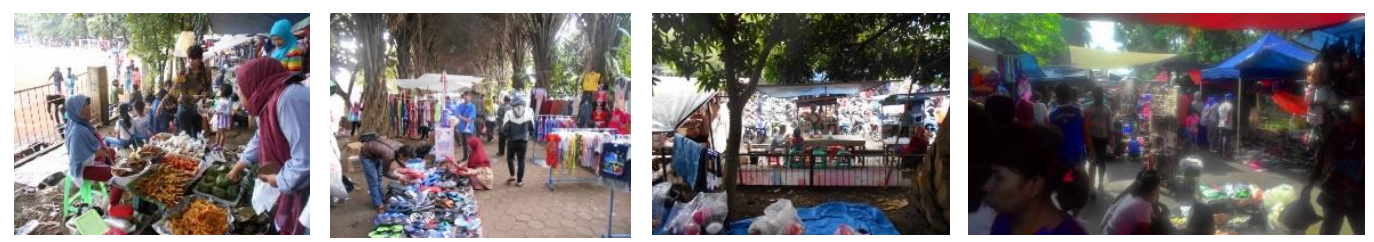

Figure 10: Image of street vendors use vehicle track areas, parking, pedestrians and green areas, source: personal analysis

\subsubsection{Mapping of Non-Commercial Activites}

The types of activities carried out by park users in this study area are recreation in which they are carried out at the soccer field running track and green area. The image of the activities in this study area is shown in Figure 11.
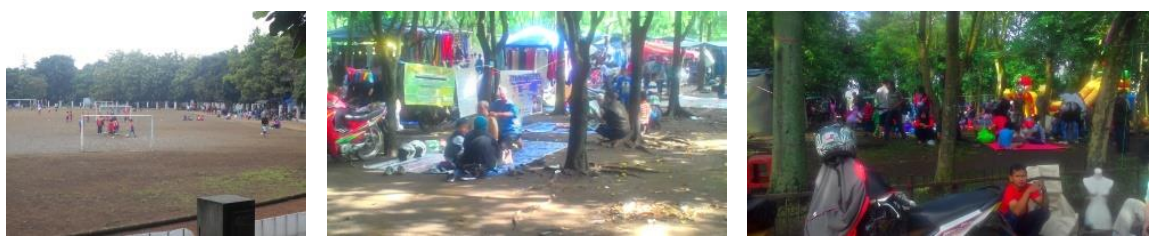

Figure 11: Images of users exercise on running tracks and soccer fields, relax and play in the green area, source: personal analysis

\subsubsection{Mapping of Density Point}

For this study area, the high density points of street vendors are at two park entrance areas on the West side, along pedestrian paths and motorised vehicle lanes adjacent to the entrance gate, green area and motorised vehicle parking area adjacent to the entrance gate. The images of the density points are shown Figure 12 and Figure 13.
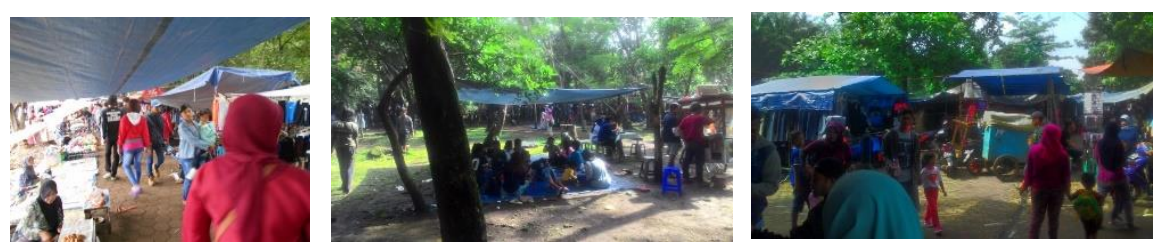

Figure 12: Image of density point at pedestrian, green and parking area source: personal analysis
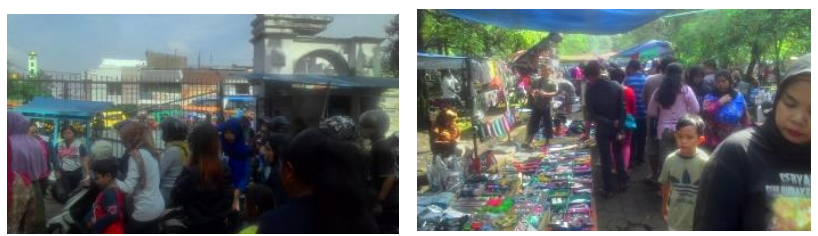

Figure 13: Image of density point at entrance gate and vehicle lanes source: personal analysis 


\subsubsection{Mapping of Physical Condition}

The physical condition of the park has deteriorated, namely in the green area and motorised vehicle parking area. The green area is damaged as it is used as a place to conduct business while the parking area of motorised vehicles becomes dirty as it is used as a garbage area. The images of the physical condition of this study area is shown in Figure 14.
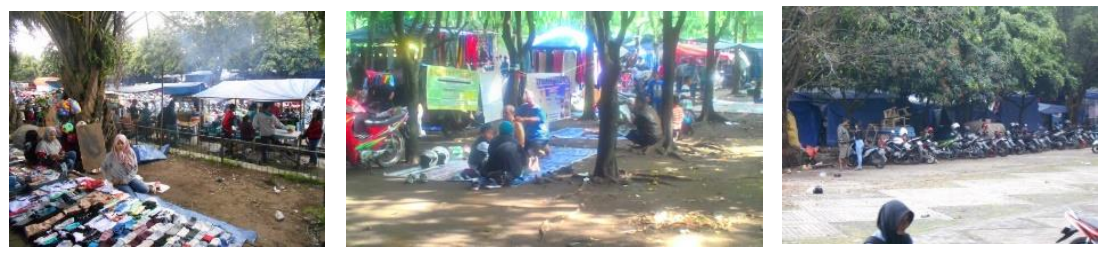

Figure 14: Image of the physical conditions of pedestrian, green and parking area source: personal analysis

\subsection{Study Area III (Zone III)}

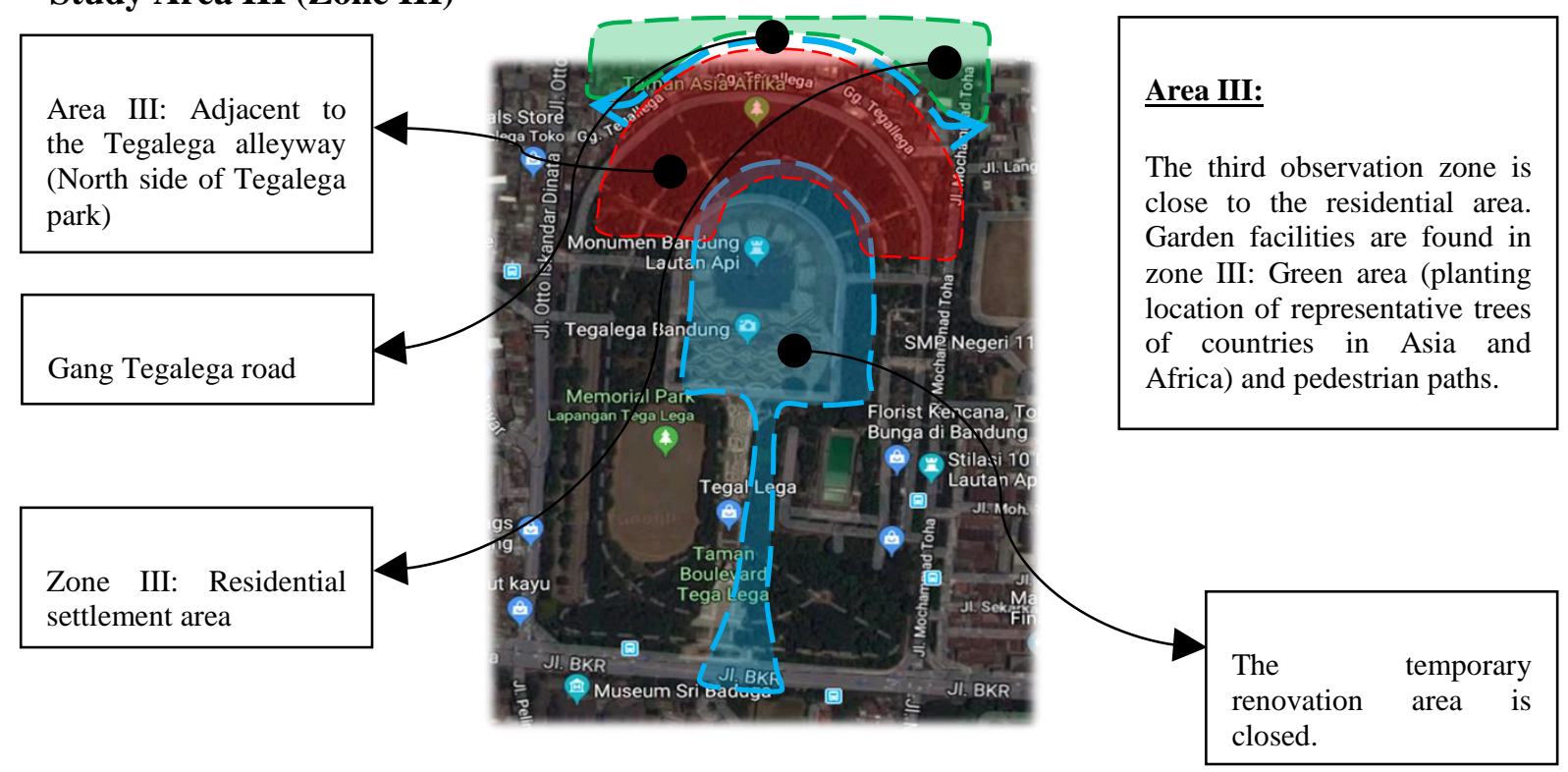

Figure 15: Zone III aerial view, source: personal analysis (map image taken from Google Map)

Study area III that is located close to Gang Tegalega road is divided into several zones, namely: pedestrian zone, motorized vehicle zone, green zone and parking zone. This area is dominated by street vendors that sell food, beverages, raw materials (food), clothing, accessories, toys, sports equipment rental services and child play facilities rental services. The sale of these items causes changes in zone designation, density and physical condition of the park. The aerial view of Zone III is shown in Figure 15.

\subsubsection{Mapping of Commercial Activities}

The street vendors at the Study Area III use pedestrian lines, motorised vehicle lanes, parking areas and green areas as business premises. The use of the area causes changes in zone designation, namely the green zone located on the north side of the park which has been turned into a street vendor zone selling food, drinks and child play facilities rental services. The green zone also been changed into a recreation area that has been made into culinary, recreation (relaxing and playing) and sports zones. Pedestrian zone which is located in the green area north of the park has turned into a zone for shopping for daily needs and fashion zones. The 
e-issn: $2229-8568$

motor vehicle lane zone which is located next to the green area at the north of the park has been turned into a street vendor that sells clothing and accessories forming fashion shopping as well as sports zones. The motorised parking area zone which is located next to the green area north of the park has been turned into a street vendor zone as well. The parking area zone has also been turned into a gymnastic activity zone which formed the play and exercise zone within the study area. The image of the usage of the area is shown as in Figure 16.
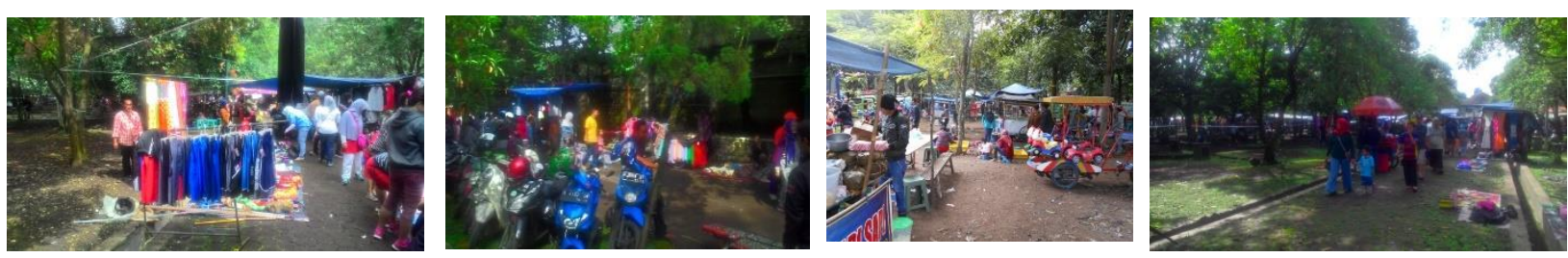

Figure 16: Images of street vendors use of vehicle track areas, sewers, pedestrians and green areas, source: personal analysis

\subsubsection{Mapping of Non - Commercial Activities}

The types of non- commercial activities carried out by users within area are in the form of relaxing (eating), playing, walking, playing badminton, relaxing (sitting), gymnastics and gathering. The location used for activities is in green areas, motorised roads, parking areas, and pedestrian paths. The images of the activities at Zone III is shown in Figure 17.
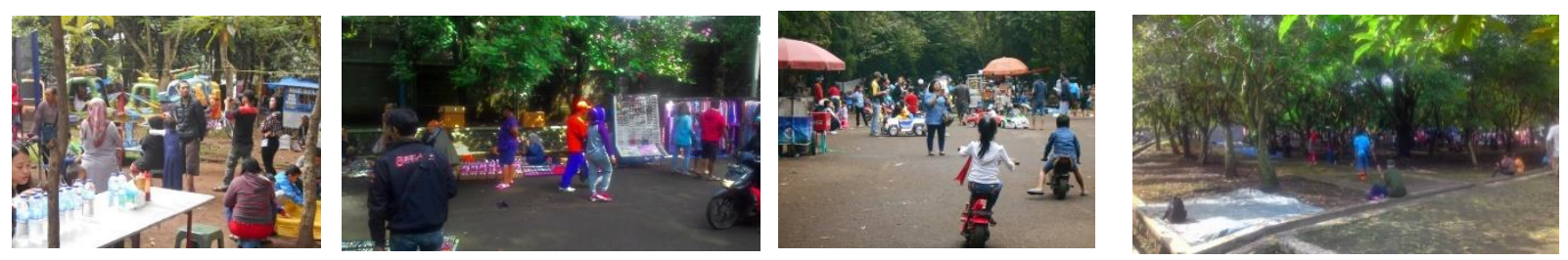

Figure 17: Image of the activities at Zone II source: personal analysis

\subsubsection{Mapping of Density Point}

The high density point for this study area are the green areas, pedestrian paths that are inside green areas and motorised vehicle parking areas. Figure 18 shows the images of density points at the selected area in zone III.
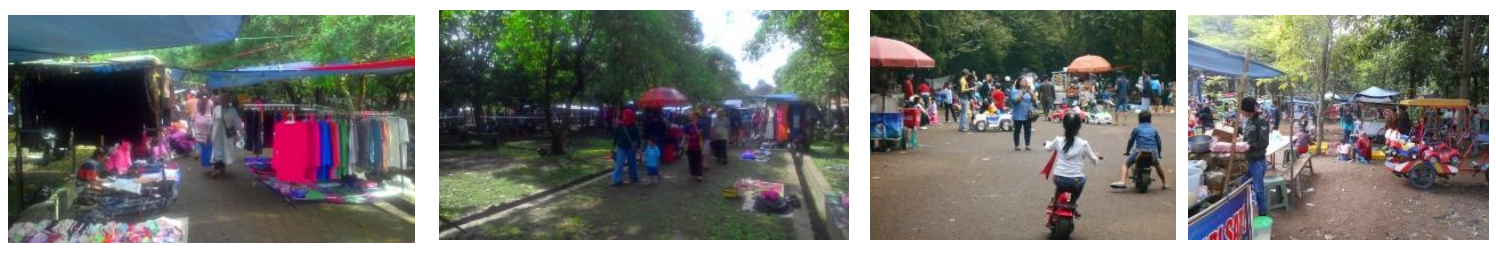

Figure 18: Density occurs in green area, pedestrian, vehicle lanes and parking area, source: personal analysis

\subsubsection{Mapping of Physical Condition}

The physical condition of the park has deteriorated, namely in the green area and pedestrian paths. The green area is damaged and it is used as a place of business, especially food and beverage traders, as well as being a chemical dump for the rest of cleaning activities 
from traders. Pedestrian paths are damaged due to being used as motorbike crossings and parking lots. The image that shows the physical conditions of the study area III is shown in Figure 19.
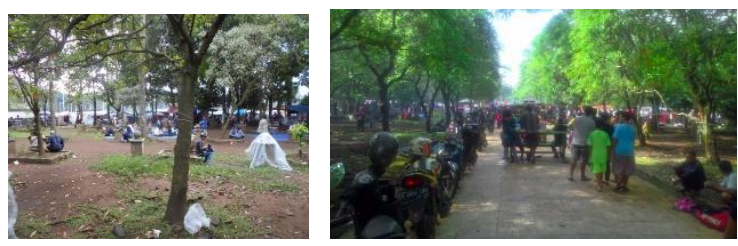

Figure 19: Decrease in physical conditions of pedestrian and green area, source: personal analysis

\subsection{Study Area IV (Zone IV)}

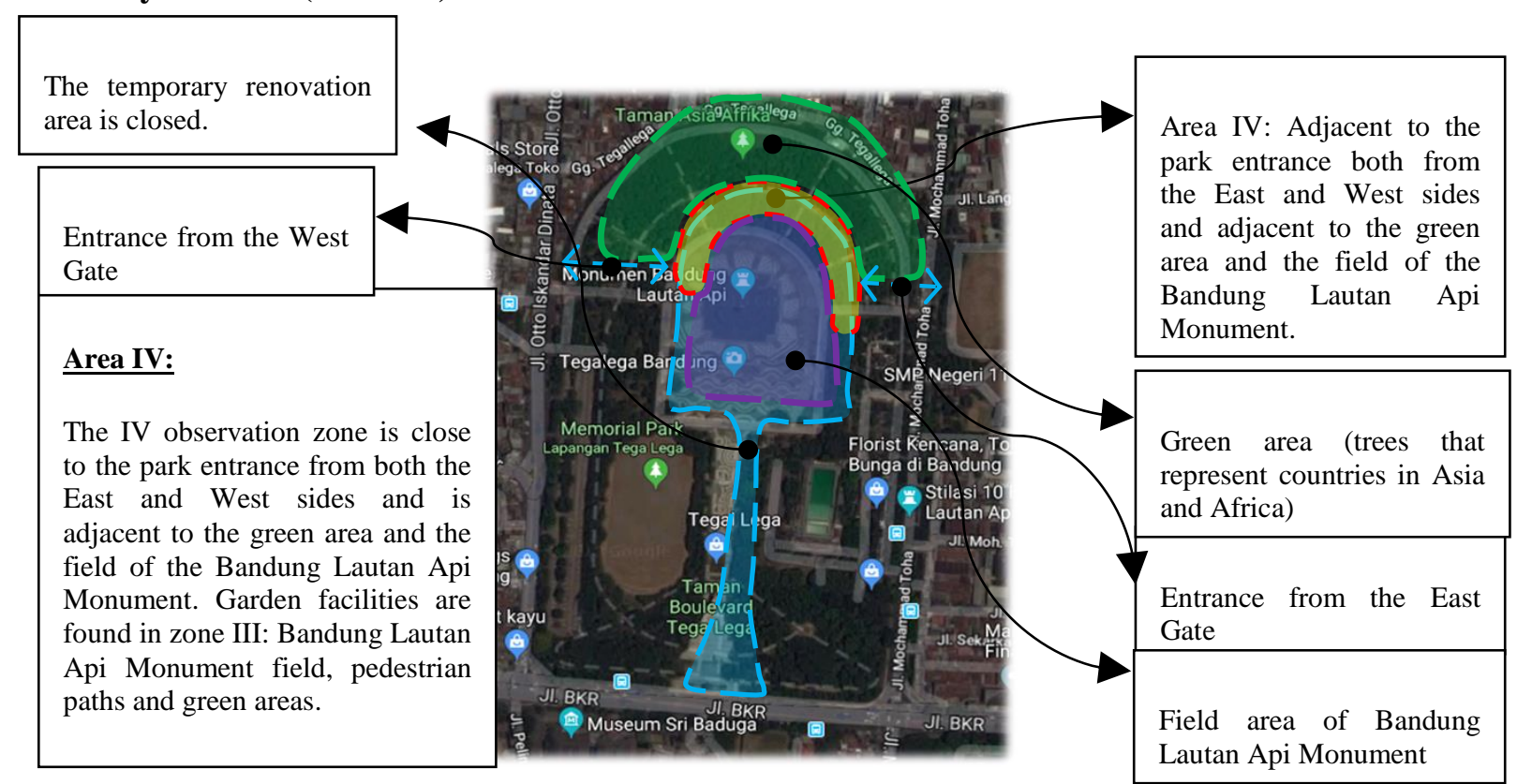

Figure 20: Zone IV aerial view

source: personal analysis (map image taken from Google Map)

The study area IV is located close to the plaza area and the Bandung Lautan Api Monument. It is divided into several zones, namely: motor vehicle zone and green zone. This area is dominated by street vendors with fashion, food and beverages. In addition, there are also street vendors who provide child playing facilities and sports equipment (badminton). This causes changes in zone designation, density and physical condition of the park. The aerial view of Zone IV is shown in Figure 20.

\subsubsection{Mapping of Commercial Activities}

The street vendors use motorised lanes and green areas in the study area as a place of business. This has caused changes in zone designation, namely: motorised vehicle lane zone near the Bandung Lautan Api monument in the centre of the park that has been turned into a street vendor zone. The zone has turned into fashion and daily needs shopping zone. The green zone that is located near the motorised vehicle lane around the Bandung Lautan Api monument's plaza is transformed into a street vendor zone namely cullinary and play zone.

Figure 21 shows the images of the commercial attention at the study area. 

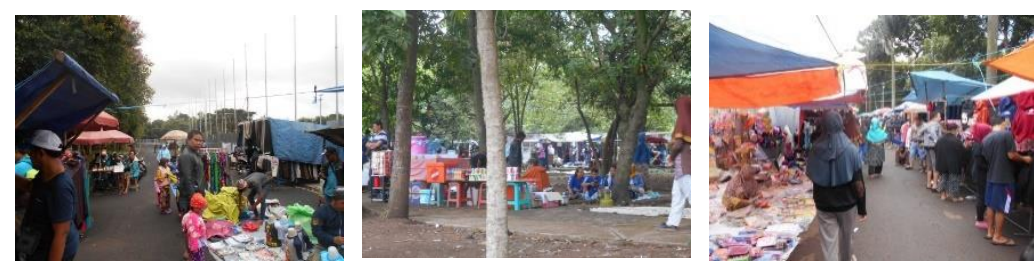

Figure 21: Images of street vendors use at vehicle track areas and green areas source: personal analysis

\subsubsection{Mapping of Non - Commercial Activities}

The type of non- commercial activities carried out by users in this study area are sports activities that are conducted at the motorised vehicles and green areas. Figure 22 shows the non- commercial activities at the study area.

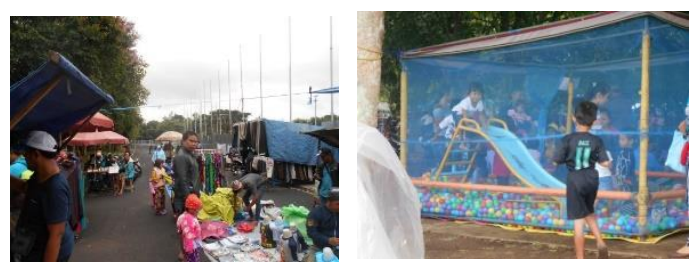

Figure 22: Images of users' activities at the lane of vehicles and green areas source: personal analysis

\subsubsection{Mapping of Density Point}

The high density point for this study area are along the paths of motorised vehicles that are between the Tugu Bandung plaza area of the Sea of Fire with green areas, as well as green areas that are adjacent to the motorized vehicle lane. Figure 23 shows the density point at the study area.
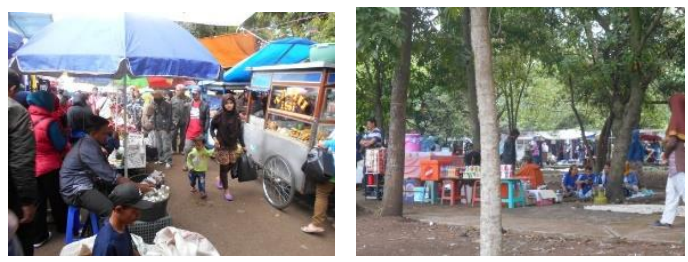

Figure 23: Images of density point at the vehicle lanes and green area source: personal analysis

\subsubsection{Mapping of Physical Condition}

The physical condition of the park has deteriorated, namely at the green area. The green area is damaged because it is used as a place of business, especially food and beverage traders, as well as being a children's playground. Figure 24 shows the physical condition of Zone IV.
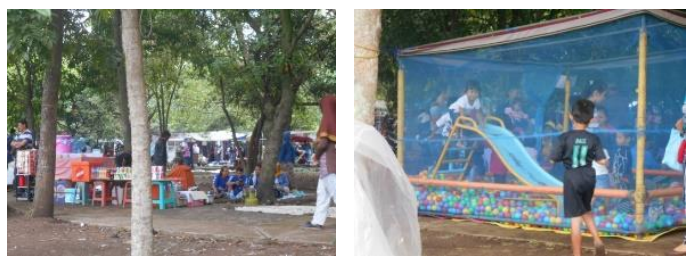

Figure 24: Images of the physical conditions of green area, source: personal analysis 


\subsection{CONCLUSION}

The effects of the street traders' activities within the Tegalaga Park are described in the previous sections. Based on the above description, Tegalega park area on the East side is dominated by shopping zones for daily needs, fashion, culinary and exercising. The West side is dominated by fashion and culinary zones while the North side is dominated by culinary and recreation zones. The central area is dominated by shopping zones for daily needs, fashion and culinary. Tegalega park area which was originally developed to facilitate sports and recreation activities has been dominated by shopping and culinary activities. The only area that is still used for sports and recreational activities is on the northen side of the park as well as small area for sports activities on the east side of the park.

The activity of street vendors in Tegalega park lead to the appearance of several points of density in the park at both the entrance area situated on the East and West of the park. The areas cover the pedestrians, motorised vehicles and green areas. The other density points are at the plaza and motorised vehicle parking areas that are adjacent to sports facilities (swimming pools and soccer fields). High density point also occurs along pedestrian lines and vehicle lanes, especially at the East, West and Tegalega park centres. It is observed that the pedestrians, motorised vehicles and green areas at the North side are not too dense. Thus, it can be concluded that the park area in the North area has the lowest density.

The physical condition of Tegalega Park has deteriorated namely the pedestrian facilities, sewers (open ditches), plazas, and especially in green areas. Pedestrian paths are damaged in the paving section as this facility is used as a crossing lane and motorised vehicle parking area. As the density is high, the high usage of the path has caused damage to the pedestrian path and the plaza. As sewers are used as a place to dispose business waste (especially organic waste), it becomes dirty and clogged. The green areas lack grass as the area is used as a place to store business tools, children's playgrounds and recreation/ sport activities. This condition has caused the park to be non-conducive for the activities that are planned for the community.

Based on the results of the study, the street vendors' (business) activities carried out in the Tegalega park have an influence on both for park users and for the park itself. This main influence is in the form of negative impacts on the park area. These influences include encroachment of spaces dedicated for visitors' amenities and sporting activities, changes in zoning from the initial planning (not suitable between use and designation), the formation of several density points in the park that disrupt the smooth running of activities and the inconvenience (difficulty in moving) of park users and hygiene condition of the space as street vendors litter the spaces unscrupulously. It is hoped that the Bandung City administrative would take into account of the highlighted impacts so that Tegalega Park can be as the public space for the community.

\subsection{REFERENCES}

1. Batlajeri, T. G. J. and Sukaesih, P. (2015). " Arrangement Policy Evaluation and Management of Street Vendors (PKL) in Bandung City." Government Science Study Program, Faculty of Social and Political Sciences, Indonesian Computer University, <http://elib.unikom.ac.id/files/disk1/ 699 / jbptunikompp-gdl-theodorusg-34913-1-unikom_ti.pdf $>$.

2. Budi, Ari S. (2006). "Location Study of Street Vendors Based on Street Vendors Preferences and Perception of Communities in Pemalang City." Thesis, Post Graduate Program of Magister Development Area and City of Diponegoro University, Semarang. 
3. Furchan, A. (2004). Research in Education, Pustaka Pelajar Offset, Yogyakarta, 54 pp .

4. Islahuddin. (2017). "The Role of Street Vendors in Overcoming Unemployment in the Perspective of Islamic Economics in the City of Makassar." Thesis, Department of Islamic Economics, Faculty of Economics and Business, State Islamic University Alauddin, Makassar.

5. Kabar24.bisnis.com. (2014). Bandung City Bappeda Create PKL Location Schemes. Retrieved October 8, 2018 from <http://kabar24.bisnis.com/>.

6. Ramadhan, R. (2015). "PKL (Street Vendors) Social - Economic Change in the Centralization Program of the Urban Informal Sector at DTC Wonokromo." Community Journal, 4 (3).

7. Pramono, Muhamad F. (2015). "Structuring and Guiding Street Vendors in Development Communication Perspectives in Surakarta (2005-2012)." Thesis, Postgraduate School of Gadjah Mada University, Yogyakarta.

8. Hafidha, Qonita N. (2014). "The Role of Stakeholders in The Management Efforts of Street Vendors in Sardjito.” Thesis, State Administration Science (Public Management and Policy) Gadjah Mada University, Yogyakarta.

9. Wicaksono, Kristian W. And Rachmawati, T. (2015). "Implementation of Regional Regulation of Bandung City Number 4 Of 2011 Concerning Regulation and Development of Street Vendors." Institute for Research and Community Service at Parahyangan Catholic University, Bandung. 